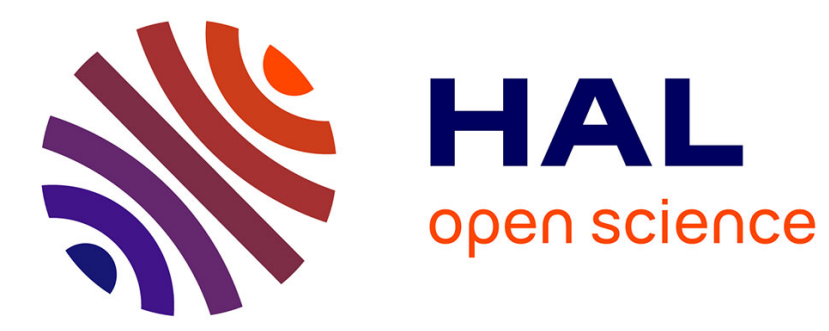

\title{
SMS experience and textisms in young adolescents
}

Josie Bernicot, Olga Volckaert-Legrier, Antonine Goumi, Alain Bert-Erboul

\section{To cite this version:}

Josie Bernicot, Olga Volckaert-Legrier, Antonine Goumi, Alain Bert-Erboul. SMS experience and textisms in young adolescents. Lingvisticae Investigationes, 2012, 35 (2), pp.181-198.

10.1075/li.35.2.04ber . hal-01392596

\section{HAL Id: hal-01392596 \\ https://hal.science/hal-01392596}

Submitted on 4 Nov 2016

HAL is a multi-disciplinary open access archive for the deposit and dissemination of scientific research documents, whether they are published or not. The documents may come from teaching and research institutions in France or abroad, or from public or private research centers.
L'archive ouverte pluridisciplinaire HAL, est destinée au dépôt et à la diffusion de documents scientifiques de niveau recherche, publiés ou non, émanant des établissements d'enseignement et de recherche français ou étrangers, des laboratoires publics ou privés. 
PRE PRINT - Bernicot, J., Volckaert-Legrier, O., Goumi, A. \& Bert-Erboul, A. (2012). SMS

Experience and Textisms in Young Adolescents: Presentation of a Longitudinally Collected Corpus. Lingvisticae Investigationes, 35(2), 181-198.

\title{
SMS Experience and Textisms in Young Adolescents: Presentation of a Longitudinally Collected Corpus
}

\author{
Josie Bernicot $^{*}$, Olga Volckaert-Legrier ${ }^{* *}$, Antonine Goumi ${ }^{* * *}$, Alain Bert-Erboul ${ }^{*}$ \\ *Université de Poitiers - CNRS \\ **Université Toulouse II - Le Mirail \\ ***Université Paris Ouest-Nanterre La Défense
}

\section{Introduction}

Text messages (SMS) have 'taken over' daily life, bringing to the fore written forms which would have been unimaginable 20 years ago (for example, "the gr $8 \mathrm{db} 8$ " or, in French, "1 pwl sr la kestion"). Studies carried out in the United States (Pew Internet and American Life Project, A. Lenhart, R. Ling, S. Campbell and K. Purcell 2010) and in France (CREDOC, L. Bigot and P. Croutte 2011) confirm this feeling, emphasizing the young age of the texters who use SMSes as a core part of their social relations. In France in 2011, 82\% of 12 to 17 year-olds had a mobile phone, and 99\% used their mobile phone to send SMSes. Over the past 10 years, the number of studies focusing on this new mode of communication has continued to grow. Consistent information in several languages is now becoming available concerning message length, speaking turns, openings, closings, spelling changes with regard to the traditional written code (textisms), gender differences (cf. the summary by C. Thurlow and M. Poff 2012, in press) as well as smileys (C. Tosell, P. Kortum, C. Shepard, L. Barg-Walkow, A. Rahmati and M. Zhong 2011). The scientific questioning with regard to SMSes has led to the construction of databases of messages produced in natural interactions. C. Fairon, J.R. Klein and S. Paumier's (2006) "sms4science" project resulted in a database containing 30,000 SMSes written by 2,436 French-speaking Belgian 'informants' between the ages of 12 and 73 .

The phenomenon of SMS use has developed so swiftly that it has not allowed scientific studies to easily grasp how texters learn this new written code. The study presented in this paper focuses on that point, by analysing the SMSes written by young adolescents between the ages of 11 and 12 during their first year of SMS use. New SMS users are confronted with a completely new interaction situation in which they are not immediately able to master all the rules. From a pragmatic point of view, a fundamental rule is the linking of the linguistic forms of utterances with the characteristics of the interaction situation (J. Austin 1962; J. Bernicot 1994; J. Bernicot and A. Mahrokhian 1989; J. Bernicot, J. Comeau and H. Feider 1994; J. Bernicot, V. Laval and S. Chaminaud 2007; P. Grice 1975; I. Noveck and D. Sperber 2004; J. Searle 1969; J. Verschueren 1999). The concepts of register (D. Ravid and L. Tolchinsky 2002) or "language variety" (D. Crystal 2001) enable the linguistic specificities of an interaction situation to be determined. It was from this angle that the current study examined a corpus of 4,524 SMSes sent by young adolescents in daily life situations and collected 
in a longitudinal manner over a period of 12 months. The objective was to show how beginning texters became able to master the structural characteristics of SMSes and, in particular, their orthographic forms (textisms). The summary of research already carried out in this area is presented below.

\section{Orthographic forms of SMSes (textisms) in young adolescents}

Early research took into account the existence of abbreviations in SMSes and calculated the percentage of SMSes with abbreviations or the percentage of participants using abbreviations. In R. Ling's (2005) corpus, $6 \%$ of the messages were written with abbreviations: girls between the ages of 13 and 15 were the greatest users of abbreviations ( $20 \%$ of their messages contained them).

More recent research has taken into account the density of textisms as a reference index. A textism is defined as a change in a word's orthographic form as compared to traditional writing. For each message, the density of textisms is equal to the number of changes divided by the total number of words in the message. Studies of children or young adolescents (9-12 years old) are rare and do not point out any specific forms of textisms for this age group. The classifications used are derived from those of C. Thurlow and A. Brown (2003) which include the following 10 categories for the English language.

- Shortenings (bro for brother)

- Contractions (gd for good)

- G-clippings (goin for going)

- Other clippings (hav for have)

- Acronyms (BFPO for British Forces Posted Overseas)

- Initialisms (V for very)

- Letter/number homophones (2moro for tomorrow)

- Misspellings (cuming for coming)

- Non-conventional spellings (fone for phone)

- Accent stylizations (afta for after)

B. Plester, C. Wood and P. Joshi (2009) asked 88 British children (mean age: 10 years and 7 months) to write out the messages that they had written on their mobile phones in 10 daily life situations (e.g.: telling a friend in class about being late due to a bus not stopping, or letting a mother know that she forgot to buy dog food). The average age at which the first mobile phone was acquired was 9 and the participants therefore had approximately one and a half years of experience. The proportion of textisms was .34 , with a difference between girls and boys (respectively .38 for girls and .28 for boys). The authors also studied the kinds of textisms and showed that two major categories stood out: simplifications (accent stylizations) which conserve the pronunciation of the spoken language (ex.: afta for after) and replacements of letters with a number homophone (e.g.: 2moro for tomorrow).

P. Plester, M. K. Lerkkanen, L. Linjama, H. Rasku-Puttonen and K. Littleton (2011) analysed the SMSes of 65 young Finnish adolescents between the ages of 9 and 11 (mean age: 10 years and 7 months). The children reported having received their first mobile phone at the age of 7 years and 3 months, and therefore they are considered as having more than 3 years of texting experience. The participants were asked to copy 
down the SMSes they had sent over the weekend and give them to the researcher when they arrived back at school. The average proportion of textisms was .48 and simplifications (accent stylizations) conserving the pronunciation of spoken Finnish dominated all the other categories. The replacements of letters with a number homophone were never used. The most-used types of textisms therefore vary from one language to another.

N. Kemp and C. Bushnell (2011) asked 86 children between the ages of 10 and 12 (mean age: 11 years and 6 months) to write a message in SMS language on a mobile phone. The message was dictated by a researcher and the participants were to imagine that they were sending it to a friend (ex: When will we see you tonight? Because someone left a message about your friend being sick. Are you sick too?). When the T9 key was deactivated (without a dictionary), the proportion of textisms was .48. The children in the sample reported that they sent on average 24 SMSes per day and had been using a mobile phone for almost two years.

C. Bushnell, N. Kemp and F.H. Martin (2011) carried out a study with 227 Australian children between the ages of 10 and 12 (mean age: 11 years and 5 months). The children were asked to write down 30 conventional words just as they would if they were using the words in a message sent to a friend. Since the children were not allowed to use their telephone at school, the test was done with paper and pencil. The results indicated that the proportion of textisms in writing task was .53.

C. Wood, E. Jackson, L. Hart, B. Plester and L. Wilde (2011a) collected, in a longitudinal fashion over 10 weekends and half-term breaks, the SMSes of 56 children between the ages of 9 and 10 (mean age: 9 years and 10 months). The participants were from the Midlands region of the United Kingdom. The children had never used a mobile phone before the beginning of the study. Depending on the weekend, the number of messages sent varied between 6 and 45, and the proportion of textisms between .12 and .16. Over the 10 weeks, no evolution in usage was shown.

C. Wood, S. Meachmen, S. Bowyer, E. Jackson, M.L. Tarczynski-Bowles and B. Plester (2011b) carried out a longitudinal study of 1,019 children between the ages of 8 and 12 (mean age: 10 years and 4 months). The participants were from the West Midlands region of the United Kingdom. The children reported owning their mobile phone since the age of 8 years and 1 month. The children were asked to provide a sample of the messages they had sent at two different time periods: at the beginning of the school year and at the end of the school year. The results showed that the average ratio of textisms went from .33 to .40 between the beginning and the end of the school year. This slight increase masks the decreases at 8 to 9 years of age and at 11 to 12 years of age which remain unexplained. Both at the beginning and at the end of the year, the textism ratio was greater for the 11 to 12 year-olds than for the 8 to 9 year-olds $(.42 / .27$ and .33/.074, respectively).

Overall, the studies carried out with children and young adolescents between the ages of 9 and 12 made use of a variety of methods ranging from the collection of natural data to the simulation of writing words in SMS language in a paper-and-pencil situation. The density of textisms revealed itself to also be highly variable: the values ranged from .074 to .53. Longitudinal studies of novice participants, such as those of Wood et al. (2011a), did not show an increase in the density of textisms with practice. This might be explained by the fact that a collection period limited to only 10 weekends was too short for an evolution to be demonstrated. It is therefore necessary to augment the existing 
data in order to have clear information regarding the orthographic forms of SMSes for the 9 to 12 year-old age group.

\section{Research objectives}

The existing research is limited and did not make use of the longitudinal method necessary for understanding the process of acquisition, with the exception of the studies carried out by C. Wood et al. (2011a) and C. Wood et al. (2011b). It should be noted that, in the first case, the study period was 10 weeks in length and, in the second case, the study period was one school year, but only one sample of SMSes is available for the beginning and the end of the year. To analyse the textisms, most of the studies either used scenarios (N. Kemp and C. Bushnell 2011; B. Plester, C. Wood and P. Joshi 2009) or were not based on an SMS collection method in an ecological condition. The methodology used in the present study enabled the collection of SMSes in natural writing conditions. Furthermore, the categories of textisms could certainly be refined so as to be adapted to young texters. Finally, the existing studies did not take into account the gender variable (girls/boys) even though some research (J. Bernicot, O. VolckaertLegrier, A. Goumi and A. Bert-Erboul 2012; A. Goumi, O. Volckaert-Legrier, A. BertErboul and J. Bernicot 2011) show differences in SMS ${ }^{1}$ length, dialogical structure and function in participants between the ages of 15 and 16. The objective of the present study was to fill in these gaps by examining, by means of a longitudinal study over a long period (12 months), how the orthographic characteristics of SMSes evolve (month by month) in young adolescents (11-12 years of age), by categorizing the textisms in terms of their distance from traditional written code.

\section{Method}

\subsection{Participants}

Nineteen young adolescents participated in the study: 10 girls and 9 boys (average age $=$ 11.79 years, $S D^{2}=.59$ of a year). They were recruited in a public secondary school in a town located in the Poitou-Charentes region of France $\left(6^{\text {th }}\right.$ and $7^{\text {th }}$ years). The pupils who had never owned or used a mobile phone were invited to participate in the study. The offer was as follows: to be equipped, free of charge, with a mobile phone for one year and to agree to "donate" to the research team at least 20 SMSes (written by the students themselves) per month. The research team guaranteed the students' anonymity at all stages of the study. The students as well as their parents provided their written consent and agreement. The participants were all from middle class families, of legal school age, and native French speakers. The participants' academic results in French class showed that they were able to write texts according to traditional rules, although they made some mistakes depending on their level.

\footnotetext{
1 The girls' messages were longer than the boys' messages and were often more relational than informational. The girls sent fewer messages which were lacking an opening and a closing (just the message) than the boys.

${ }^{2}$ SD: Standard Deviation
} 


\subsection{Materials}

The materials consisted of a Sony Ericsson model J132 or Alcatel model OT-303 mobile phones (French models). These two open-face (non-flip style) mobile phone models with a nine-key keyboard are similar. The T9 key, which enabled predictive text and access to a dictionary, was deactivated. The cards which served to recharge the mobile phones were, on the one hand, cards worth $€ 15$ (equivalent to 30 minutes of voice communication or 150 SMSes) and, on the other hand, cards worth $€ 5$ and valid for five days with unlimited SMSes. A 3G key and the Vodafone Mobile Connect software (a screenshot of this software is provided in Appendix A) installed on a computer allowed the research team to receive the SMSes which were 'donated' each month by the participants.

\subsection{Procedure}

The procedure for collecting the SMSes is summarized in Table 1. At the beginning of each month, the participants' mobile phones were automatically credited with a sum of $€ 15$, the equivalent of 30 minutes of voice communication or 150 SMSes. Once per month, the participants' mobile phones were also credited with the sum of $€ 5$, allowing an unlimited number of SMSes to be sent over a period of five days. It was during this period that the participants were to send at least 20 SMSes to the research team, freely chosen from the SMSes that they had sent throughout the month and that they had written themselves. These SMSes, with the help of the $3 \mathrm{G}$ key, were received onto a computer by means of the Vodafone SMS software. Using this software, a "cut and paste" procedure enabled the SMSes to be entered into the cells of a Microsoft Excel workbook. This procedure was repeated for 12 months.

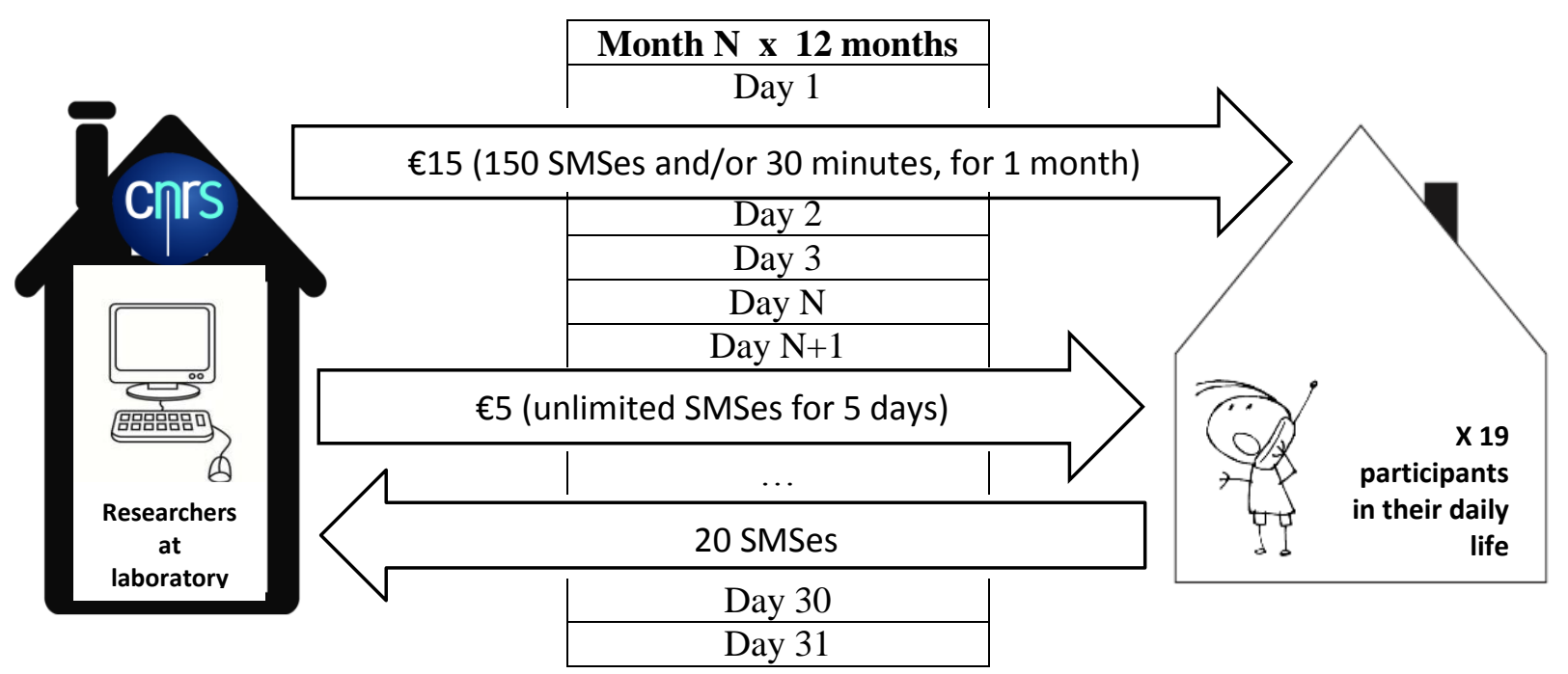

Table 1. Stages of the SMS collection procedure 


\begin{tabular}{|c|c|c|}
\hline $\begin{array}{c}\text { Text } \\
\text { message } \\
\text { No } \\
\end{array}$ & Original SMSes in French & $\begin{array}{l}\text { English translations into traditional } \\
\text { French of SMSes in transcribed form }\end{array}$ \\
\hline 1 & Es ke jordan a un portable & Does Jordan have a mobile phone \\
\hline 2 & Jlui et di je sai pa & I told him I don't know \\
\hline 3 & $\begin{array}{l}\text { Cc c megane Tu y sera ver kel heur au } \\
\text { stade mercredi? }\end{array}$ & $\begin{array}{l}\text { Hey it's Mégane around what time will you } \\
\text { be at the stadium Wednesday? }\end{array}$ \\
\hline 4 & 3 ou 4 & 3 or 4 \\
\hline 5 & Chui ché des gen et je menui & I'm at some people's house and I'm bored \\
\hline 6 & $\begin{array}{l}\text { Ouai dmin et c ke laprèm Si tu vien fo } \\
\text { ke tu révise pars ky a un control en } \\
\text { histoir }\end{array}$ & $\begin{array}{l}\text { Yeah t'morrow and it's that in the } \\
\text { afternoon if you come you have to study } \\
\text { because there's a history test }\end{array}$ \\
\hline 7 & $\begin{array}{l}\text { Jai resu ton mésage mai pourquoi tu ma } \\
\text { envoyé ça? }\end{array}$ & $\begin{array}{l}\text { I got your message but why did you send } \\
\text { me that? }\end{array}$ \\
\hline 8 & $\begin{array}{l}\text { Cc J'ai une mauvaise nouvelle pour toi } \\
\text { marine veu pa sortir avec toi Dsl }\end{array}$ & $\begin{array}{l}\text { Hey I have some bad news for you Marine } \\
\text { does not want to go out with you sorry }\end{array}$ \\
\hline 9 & $\begin{array}{l}\text { Ouai ta raison Tu me dira si ya des } \\
\text { nouvel }\end{array}$ & $\begin{array}{l}\text { Yeah you're right tell me if you hear } \\
\text { anything }\end{array}$ \\
\hline 10 & $\begin{array}{l}\text { Non mai jvai à crepigny ché mon } \\
\text { tonton et je vai mennuyé à mourir } \\
\text { Pourkoi t au stade? }\end{array}$ & $\begin{array}{l}\text { No but I'm going to Crépigny to my } \\
\text { uncle's place and I'm going to die of } \\
\text { boredom Why are you at the stadium? }\end{array}$ \\
\hline 11 & A ok Ta fé té maths? & Ah ok did you do your maths? \\
\hline 12 & Ladresse de ché ele? & Her home address? \\
\hline 13 & $\begin{array}{l}\text { Dsl jui pa a crepigny Jui en train de me } \\
\text { baigné Mé normalemen jiré au foot } \\
\text { vendredi prochain }\end{array}$ & $\begin{array}{l}\text { Sorry I'm not in Crépigny I'm swimming } \\
\text { but I should be going to football next } \\
\text { Friday }\end{array}$ \\
\hline 14 & A ok Et tu fé koi Ya un match & $\begin{array}{l}\text { Ah ok and what are you up to is there a } \\
\text { match }\end{array}$ \\
\hline 15 & Nou on sor just de la piscine & We just got out of the pool \\
\hline 16 & $\begin{array}{l}\text { Cc dsl si je t pa répondu hier soir } \mathrm{C} \\
\text { parce ke jai étin mon portable }\end{array}$ & $\begin{array}{l}\text { Hey sorry I didn't get back to you last } \\
\text { night it's because I turned off my mobile }\end{array}$ \\
\hline 17 & $\begin{array}{l}\text { Es ke demain tu poura amené ta trouce } \\
\text { ou ya tou t badge stp }\end{array}$ & $\begin{array}{l}\text { Tomorrow can you bring your case where } \\
\text { you keep all your cards please }\end{array}$ \\
\hline 18 & Pk tu rép pa a ana & Why won't you answer Ana \\
\hline 19 & Cc c vrai ke tu sor avec marine & $\begin{array}{l}\text { Hey is it true that you're going out with } \\
\text { Marine }\end{array}$ \\
\hline 20 & Ba parce ke jaime bien tenbêté & Ha because I really like messing with you \\
\hline
\end{tabular}

Table 2. SMSes from participant No 10 for month 1 The participant was a girl who was 12 years and 7 months old 
The participants respected their agreement by providing a total of 4,524 messages ${ }^{3}$ : on average, per participant, 19.84 SMS $(S D=3.02)$ per month and 238.10 SMS $(S D=$ 36.24) for the year. The data collection took place throughout the 2009-2010 academic year. As an example, Table 2 presents the SMSes (with their original form in French and their transcribed form in traditional French) of participant No 10 for month 1.

\subsection{Coding}

Two indexes were taken into consideration: the type of textisms and the density of textisms. A textism is defined as a change in the orthographic form of a word as compared to traditional writing. For each message, the density of textisms was equal to the number of words with changes divided by the total number of words in the message.

The coding of the textisms was based, on the one hand, on the analytical grids of the English language (R. Grinter and M.A. Eldridge 2003; B. Plester, C. Wood and P. Joshi 2009; C. Thurlow and A. Brown 2003) and on the grids dedicated to the French language (J. Anis 2007; R. Panckhurst 2009). R. Panckhurst (2010) showed the particularities of French (in SMS language) as compared to Italian and Spanish. E. Stark (2011) studied the morphosyntax in SMSes written in Swiss French, and examined SMSes in the three languages (French, German, Italian) spoken in Switzerland (E. Stark and C. Dürscheid 2011). In this study, it was deemed important to distinguish between the two large types of textisms with regard to their accordance with, or rupture from, traditional written code. From a cognitive point of view, the first case involves a different application of the same rules, while in the second case; there is an application or invention of different rules.

a) The textisms which were consistent with the traditional code of grapheme-phoneme correspondence: the orthographic changes did not modify the phonology (pronunciation) of the words and were carried out with graphic forms which exist in traditional writing.

b) b) The textisms which broke with the traditional code of graphemephoneme correspondence: the orthographic changes modified the phonology (pronunciation) of the words and/or were carried out with graphic forms which do not exist in traditional writing.

Table 3 presents the different sub-categories together with examples.

All of the categories of C. Thurlow and A. Brown (2003) were found in this study, except for "g-clippings", which are specific to the English language. The category of "agglutinations", made up of words placed one after the other without a space ("patavoir" [nothaveyou] instead of "pas t'avoir" [not have you], or "jcroyé" [ithot] instead of "je croyais" [i thought]), was highlighted, and this has no equivalent in the classification of C. Thurlow and A. Brown (2003).

With regard to the coding of the different types of textisms with the categories of this study, a very high intercoder agreement of $99.68 \%$ was found, using 250 messages chosen at random and containing 940 textisms.

\footnotetext{
${ }^{3}$ All of the text messages sent by the participants were taken into consideration, except for the text messages which were 'chain letters' or 'spam' (by definition not written by the participants themselves).
} 


\begin{tabular}{|c|c|c|}
\hline \multicolumn{3}{|c|}{ Textisms which were consistent with the traditional grapheme-phoneme correspondence code } \\
\hline Categories & Examples & $\begin{array}{c}\text { Traditional transcriptions in } \\
\text { French }\end{array}$ \\
\hline \multirow[t]{6}{*}{ Simplifications } & é & et \\
\hline & donné & donner \\
\hline & koi & quoi \\
\hline & biz & bise \\
\hline & tro & trop \\
\hline & concer & concert \\
\hline \multirow[t]{2}{*}{ Complexifications } & lessons & leçon \\
\hline & j'ai male & j’ai mal \\
\hline \multirow[t]{3}{*}{ Substitutions } & chanbre & chambre \\
\hline & es & ai \\
\hline & fais & fait \\
\hline \multicolumn{3}{|c|}{ Textisms breaking with the traditional grapheme-phoneme correspondence code } \\
\hline Categories & Examples & $\begin{array}{l}\text { Traditional transcriptions in } \\
\text { French }\end{array}$ \\
\hline \multirow{4}{*}{$\begin{array}{l}\text { New grapheme-phoneme } \\
\text { correspondences without } \\
\text { modification of phonology }\end{array}$} & mwa & moi \\
\hline & qi & qui \\
\hline & dem1 & demain \\
\hline & ct & c'était \\
\hline \multirow[t]{2}{*}{ Agglutinations } & entrain & en train \\
\hline & jcroyé & je croyais \\
\hline \multirow[t]{4}{*}{ Modifications of phonology } & $\mathrm{pk}$ & pourquoi \\
\hline & jtdgdt & je t'adore grave de trop \\
\hline & couz & cousine \\
\hline & chpa & je ne sais pas \\
\hline \multirow{5}{*}{$\begin{array}{l}\text { Words or graphic forms which do } \\
\text { not exist in traditional French }\end{array}$} & $\mathrm{mdr}$ & mort de rire \\
\hline & jtkife & je t'aime \\
\hline & ouiiiiiiiiiiiiiiiiiiiii & $\begin{array}{l}\text { Repeated letters as an expression of } \\
\text { urgency }\end{array}$ \\
\hline & pfff & New onomatopoeia \\
\hline & $: 2$ & Smiley expressing sadness \\
\hline
\end{tabular}

Table 3. Examples of different categories of textisms which were consistent with or breaking with the traditional grapheme-phoneme correspondence code

\section{Results}

\subsection{Different types of textisms}

Table 4 provides an overall view of the distribution of the different types of textisms. In the corpus used in this study, the average proportion of textisms was .52, which meant that slightly more than half of the words produced by the participants contained a change with regard to traditional spelling and that slightly less than half contained no changes.

\section{Proportion of words with textisms} .52 Proportion of words without textisms .48 


\begin{tabular}{|l|l|}
\hline \multicolumn{2}{|c|}{ Textisms which were consistent with the traditional code } \\
\hline Categories & Proportions \\
\hline Simplifications & $\mathbf{. 2 3}$ \\
\hline Complexifications & .01 \\
\hline Substitutions & .02 \\
\hline TOTAL & $\mathbf{. 2 6}$ \\
\hline
\end{tabular}

Table 4. Proportions of words with textisms for each category of textisms

Among the words with textisms, half (.26) were consistent with traditional code and the other half $(.26)$ broke with this code. For the textisms which were consistent with the traditional code, simplifications made up the largest proportion (.23). For the textisms which broke with the traditional code, graphemes which led to a modification of the phonology made up the largest proportion (.13).

\subsection{The density of textisms}

First, with the participants as the random variable, the results were processed by means of a one-way ANOVA (analysis of variance): SMS experience (months 1 to 12). The dependent variable was the density of textisms: the total number of textisms divided by the number of words per message.

Textisms for all the categories combined

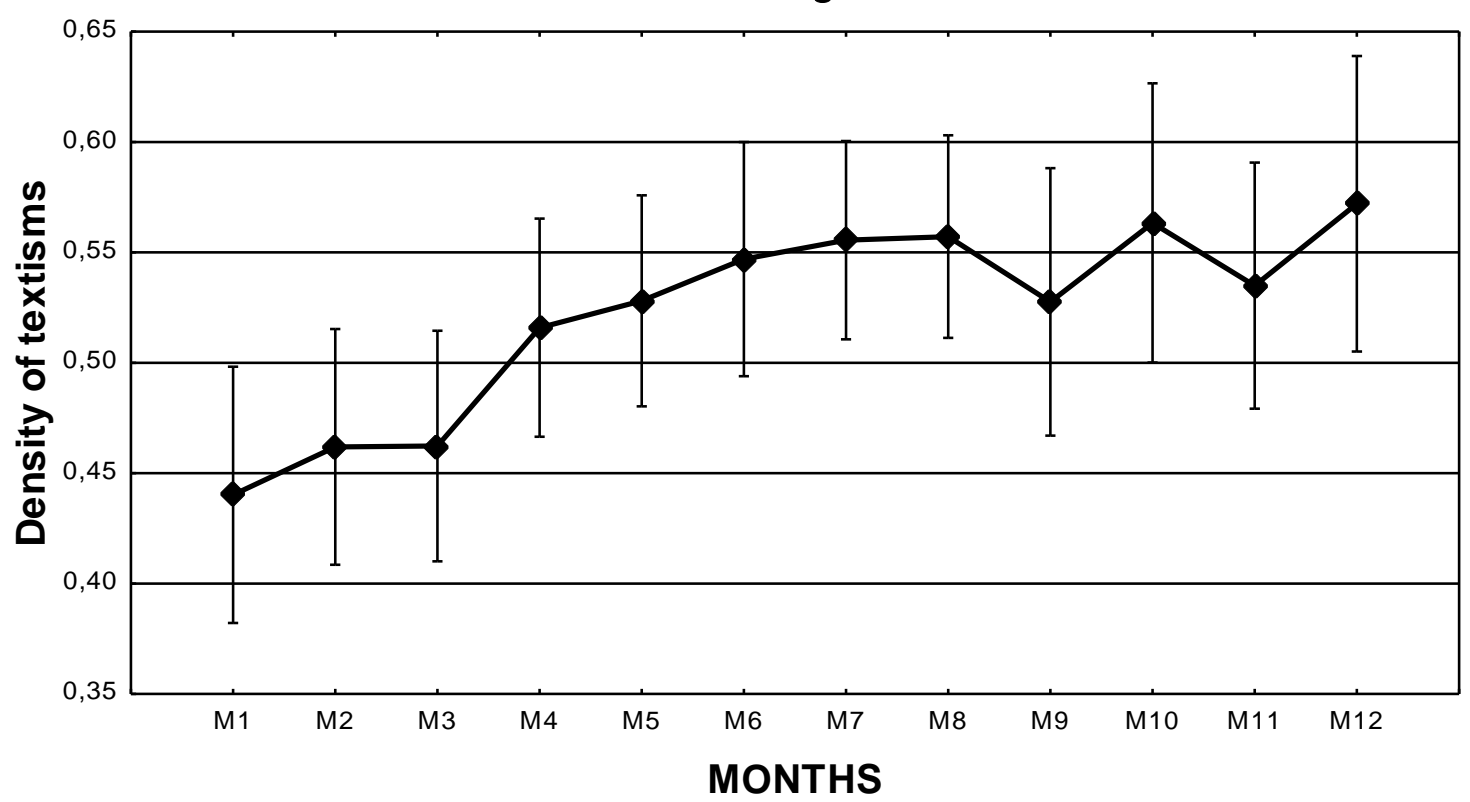

Figure 1. Evolution of textism density over one year by months (M) of SMS experience

The vertical bars represent the standard deviations 
The effect of SMS experience was significant, $F(11,198)=3.90, p<.00004, \eta^{2}=.18$ : on the whole, the density of textisms rose from month 1 (average $=.44$ ) to month 12 (average $=.57)(\mathrm{cf}$. Figure 1).

For the textisms which were consistent with the traditional code, the results were processed by means of a two-factor ANOVA: SMS experience (months 1 to 12) $\mathrm{x}$ gender (female/male). The dependent variable was the density of textisms: the number of textisms consistent with the traditional code divided by the number of words per message.

The interaction effect between SMS experience and gender was significant, $F(11,187)=2.54, p<.005, \eta^{2}=.13$. For girls, this density (cf. Figure 2 ) remained stable over the months, while for boys, the increase between month 1 and month 12 was significant, $F(1,17)=6.00, p<.02$. Furthermore, for months 7 to 12 grouped together, boys produced significantly more textisms which were consistent with the traditional code than girls did $F(1,17)=6.40, p<.02$.

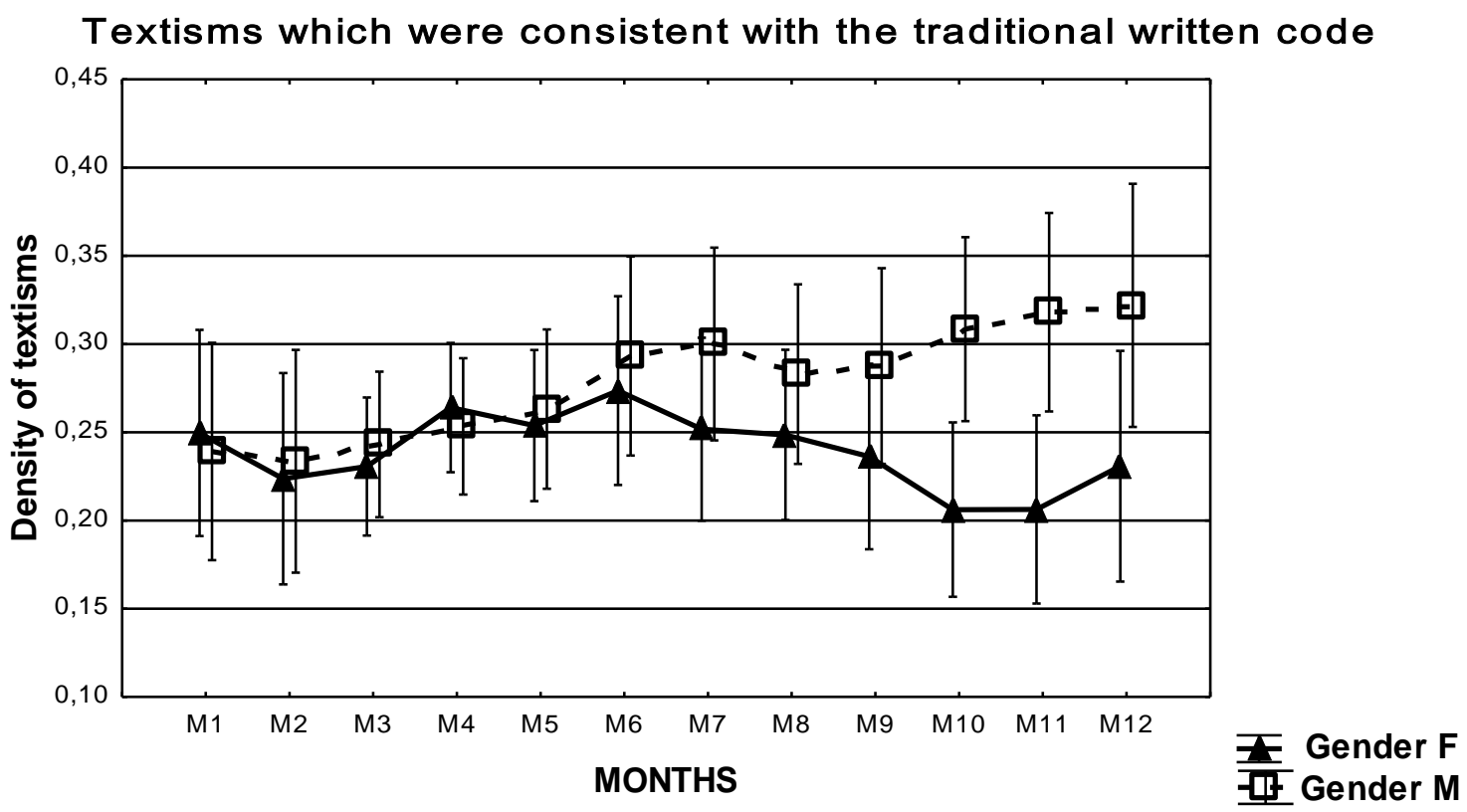

Figure 2. Evolution over one year of the density of textisms which were consistent with the traditional code by months (M) of SMS experience and gender (F: female, M: male)

The vertical bars represent the standard deviations

For the textisms which broke with the traditional code, the results were also processed by means of a two-factor ANOVA: SMS experience (months 1 to 12) $\mathrm{x}$ gender (female/male). The dependent variable was the density of textisms: the number of textisms breaking with the traditional code divided by the number of words per message.

The effect of SMS experience was significant $F(11,187)=2.40, p<.008, \eta^{2}=.12$. No significant interaction effect for SMS experience $\mathrm{x}$ gender was found. For both girls and boys, there was an increase from month 1 to month 12 (cf. Figure 3 ). 


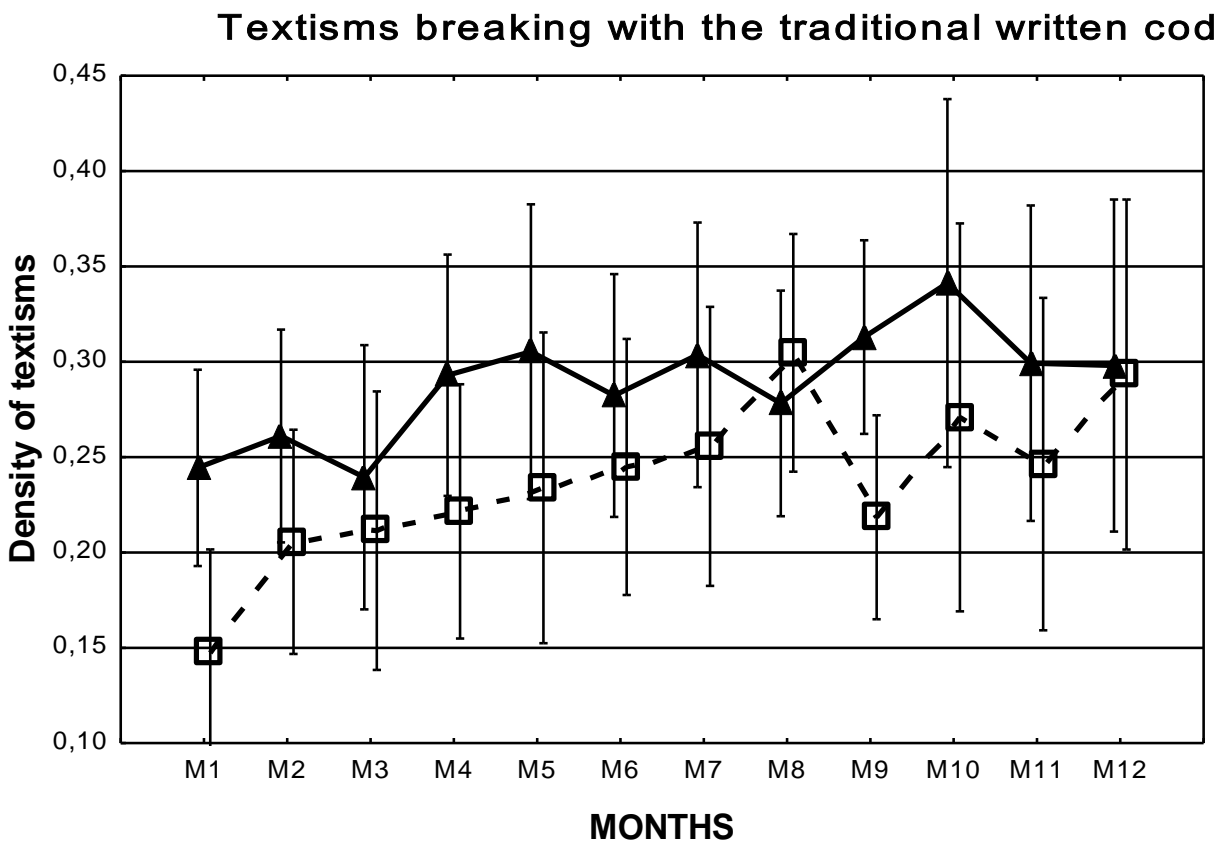

Figure 3. Evolution over one year of the density of textisms which broke with the traditional code by months (M) of SMS experience and gender (F: female, M: male)

The vertical bars represent the standard deviations

\section{Conclusions}

The first objective of this study was to compile a corpus of SMSes written by young adolescents between the ages of 11 and 12. This goal was achieved: 4,524 SMSes produced by participants who had no experience at the start of the collection which lasted 12 months and included one collection per month. The technique which was used guaranteed that the SMSes were those written in daily life situations by the participants. The corpus, in French, added to that of C. Fairon, J.R. Klein and S. Paumier (2006) et E. Stark et al. (2011) ("sms4science") by providing data from younger texters (11 to 12 years of age), and whose productions were observed over a one-year period.

The first result was that the density of textisms increased with SMS experience (between month 1 and month 12 of the collection). In one year, the average grew from .44 to .57 with large variances: For example, in month 12 , the smallest density value was .21 and the greatest value was .79. Differences, then, were observed from one participant to the other, but a general trend existed of a high density from the very first month and an increase in this density of textisms with SMS experience.

How might the high density of textisms produced by the novice users in the first month be explained? An initial explanation might point to a particularly weak level of spelling in traditional writing. Yet, as was mentioned earlier in this paper when the participants were presented, this was not the case: where spelling was concerned, all of these participants met the expectations of the academic system. A second explanation might be an immediate adaptation to the new writing context of the mobile phone: even if they had never used one themselves, the participants 'knew' by cultural transmission 
that SMS rules were not the same as classroom writing rules. This second hypothesis needs to be verified by means of a survey of novice users.

The average density of textisms that was observed (.57 after one year of experience) was greater than those found in comparable collections carried out with the longitudinal method: .16 for C. Wood et al. (2011a) and .40 for C. Wood et al. (2011b). Additional research will make it possible to determine whether this difference in results was due to the language (French/English) or the collection techniques. In the study carried out by C. Wood et al. (2011b), the density of textisms was .33 in the first month of the collection with participants who had, on average, two years of SMS experience; in the present study, it was .44 for participants who had no experience at all. This study aimed to go further than an analysis of the density of textisms by considering the type of textisms and the gender of the participants. The distinction between the two types of textisms (consistent with or breaking with the traditional written code) was based upon the different cognitive processes which make a deeper analysis possible. On the whole, the density of textisms was .52 , with a density of .26 for textisms which were consistent with the traditional written code, and the same density of .26 for those which broke with this code.

For the textisms which were consistent with the traditional code, the same rules were applied in a different way: for example, by simplifying "donner [to give]" and making it "donné", the phoneme-grapheme code is respected "differently". Instead of transcribing the "é" by the grapheme "er" (which is pronounced the same way) which is expected in terms of morphosyntax, it is transcribed by using another existing and phonologically possible grapheme, the letter "é". The evolution with use is not the same for girls as for boys: for girls, the density remains stable, while for boys, it increases with use. For the last months (7 to 12), the density of textisms which were consistent with the traditional written code was higher for boys than for girls.

For textisms which broke with the traditional code, a new rule was applied or invented: For example, by writing "jtdgdt" for "je t'adore grave de trop" [I love you way too much], a message is produced which cannot be decrypted (or pronounced) using the traditional phoneme-grapheme traditional written code. A new rule is used, which leads to a new convention being used by those who have mastered the SMS register. The evolution with use is the same for girls as for boys: the density increases with use. At month 12 , girls produced $57 \%$ of textisms which broke with the traditional code, while boys only made $47 \%$. For this new variable, the results are analogous with the data obtained in other areas: girls tend to master the characteristics of an SMS register earlier than boys (J. Bernicot, O. Volckaert-Legrier, A. Goumi and A. Bert-Erboul 2012; A. Goumi, O. Volckaert-Legrier, A. Bert-Erboul and J. Bernicot 2011; C. Thurlow and M. Poff 2012, in press).

This study demonstrated the importance of carrying out an in-depth analysis of textisms in terms of the cognitive processes involved by going further than the description of the orthographic changes with regard to the traditional written code. Continuing in this direction will make it possible to show and provide a convincing argument for the fact that SMSes are not an example of the deterioration of traditional writing, but instead constitute a register of their own which belongs to a very precise situation of communication (D. Crystal 2001; D. Ravid and L. Tolchinsky 2002): written correspondence with close friends and relatives by means of a mobile phone. 


\section{Acknowledgments}

This research was supported by the French National Research Agency project ANR-08COMM-011-01 entitled "Adolescents and Computer-Mediated Writing: Prerequisites, Uses, and Learning”. Special thanks are extended to Martha Randy for translating this paper.

Paper accepted by Lingvisticae Investigationes (November 2012, revised version).

\section{References}

Anis, Jacques. 2007. Neography: Unconventional spelling in French SMS text messages. In The multilingual internet: Language, culture and communication on line, B. Danet, S.C., Herring, (eds), New York, Oxford University Press.

Austin, John L. 1962. How to do things with words. Cambridge, Massachusetts: Harvard University Press.

Bernicot, Josie. 1994. Speech acts in young children: Vygotski's contribution. European Journal of Psychology of Education 9: 311-320.

Bernicot, Josie; Alénouche Mahrokhian. 1989. To ask and to insist after a refusal: how do 6-7-year-old children proceed? International Journal of Psychology, No 3-4: 389-407.

Bernicot, Josie; Judith Comeau; Helga Feider. 1994. Dialogues between French-speaking mothers and daughters in two cultures: France and Quebec. Discourse Processes 18: 19-34.

Bernicot, Josie; Virginie Laval; Stéphanie Chaminaud. 2007. Nonliteral Language Forms in Children: In What Order Are They Acquired in Pragmatics and Metapragmatics? Journal of Pragmatics 39: $2115-$ 2132.

Bernicot, Josie; Olga Volckaert-Legrier, Antonine Goumi, Alain Bert-Erboul. 2012. Forms and Functions of SMS Messages: A Study of Variations in a Corpus Written by Adolescents. Journal of Pragmatics 44: 1701-1715.

Bigot, Régis; Patricia Croutte. 2011. La diffusion des technologies de l'information et de la communication dans la société française. Paris: CREDOC.

Bushnell, Catherine; Nenagh Kemp; Frances Heritage Martin. 2011. Text-messaging practices and links to general spelling skill: a study of Australian children. Australian Journal of Educational \& Developmental Psychology 11: 27-38

Crystal, David. 2001. Language and Internet. Cambridge: Cambridge University Press.

Fairon, Cedrick; Jean René Klein; Sébastien Paumier. 2006. SMS pour la science. Corpus de 30.000 SMS et logiciel de consultation. Louvain-la-Neuve, Presses Universitaires de Louvain.

Goumi, Antonine; Olga Volckaert-Legrier; Alain Bert-Erboul; Josie Bernicot. 2011. SMS length and function: a comparative study of 13 to 18 year-old girls and boys. European Review of Applied Psychology 61(4): 175-184.

Grice, Paul. 1975. Logic and conversation. In Syntax and Semantics 3: Speech Acts, P. Cole, J. Morgan (eds), New York: Academic Press.

Grinter, Rebecca E; Margery A Eldridge. 2001. Y do tngrs luv 2 txt msg? In Proceedings of the seventh European Conference on Computer-Supported Cooperative Work, W. Prinz, M. Jarke, Y. Rogers, K. Schmidt, V. Wulf (eds), Netherlands: Kluwer Academic Publishers.

Kemp, Nenagh; Catherine Bushnell. 2011. Children's text messaging: abbreviations, input methods and links with literacy. Journal of Computer Assisted Learning 27: 18-27. 
Josie Bernicot, Olga Volckaert-Legrier, Antonine Goumi, Alain Bert-Erboul

Lenhart, Amanda; Ling Rich; Scott Campbell; Kristen Purcell. 2010. Teens and Mobile Phones. Pew Internet and American Life Project. Retrieved 18 July 2012 from http://www.pewinternet. org/ /media//Files/Reports/2010/PIP-Teens-and-Mobile-2010-with-topline.pdf

Ling, Richard. 2005. The socio-linguistics of SMS: An analysis of SMS use by a random sample of Norwegians. In Mobile communications: Renegotiation of the social sphere R. Ling and P.E. Pedersen (eds), London: Springer.

Noveck, Ira; Dan Sperber. 2004. Experimental Pragmatics. Basingstoke, England: Palgrave.

Panckhurst, Rachel. 2009. Short Message Service (SMS) : typologie et problématiques futures. In Polyphonies, pour Michelle Lanvin, T, Arnavielle, (ed.), Université Paul-Valéry: Montpellier 3.

Panckhurst, Rachel. 2010. Texting in three European languages: does the linguistic typology differ?, Actes du Colloque i-Mean 2009 Issues in Meaning in Interaction, University of the West of England, Bristol, April.

Plester, Beverly; Marja-Kristiina Lerkkanen; Lauri Linjama; Helena Rasku-Puttonent; Karen Littleton. 2011. Finnish and UK English pre-teen children's text message language and its relationship with their literacy skills. Journal of Computer Assisted Learning 27: 37-48.

Plester Beverly A.; Clare Wood; Puja Joshi. 2009. Exploring the relationship between children's knowledge of text message abbreviations and school literacy outcomes. British Journal of Developmental Psychology 27: 145-162.

Ravid, Dorit; Liliana Tolchinsky. 2002. Developing linguistic literacy: a comprehensive model. Journal of Child Language 29: 419-448

Searle, John. R. 1969. Speech acts. Cambridge, MA: Cambridge University Press.

Stark, Elisabeth, 2011. La morphosyntaxe dans les SMS suisses francophones: Le marquage de l'accord sujet - verbe conjugué. Linguistik online 48 (4). Retrieved 18 July 2012 from http://www.linguistikonline.de/48_11/stark.htm.

Stark, Elisabeth; Christa Dürscheid, 2011. SMS4science: An international corpus-based texting project and the specific challenges for multilingual Switzerland". In Digital Discourse. Language in the New Media: 299-320, Crispin Thurlow and Kristine Mroczek (eds). Oxford: Oxford University Press.

Tossell, Chad, C.; Philip Kortum; Clayton Shepard; Laura H Barg-Walkow; Ahmad Rahmati; Lin Zhong. 2011. A Longitudinal Study of Emoticon Use in Text Messaging from Smartphones. Computers in Human Behavior 28: 659-663.

Thurlow, Crispin; Alex Brown. 2003. Generation Txt? The sociolinguistics of young people's textmessaging. Retrieved 28 July 2010 from http://faculty.washington.edu/thurlow/papers/Thurlow (2003)-DAOL.pdf.

Thurlow, Crispin; Michele Poff. 2012, in press. The language of text messaging. In Handbook of the pragmatics of CMC, S.C Herring; D. Stein; T. Virtanen (eds), Berlin and New York: Mouton de Gruyter.

Verschueren, Jeff. 1999. Understanding pragmatics. London: Arnold.

Wood, Clare; Emma Jackson; L Hart; Beverly Plester; Lucy Wilde. 2011a. The effect of text messaging on 9- and 10-year-old children's reading, spelling and phonological processing skills. Journal of Computer Assisted Learning 27: 28-36.

Wood, Clare; Sally Meachem; Samantha Bowyer; Emma Jackson; M. Luisa Tarczynski-Bowles; Beverly Plester. 2011b. A longitudinal study of children's text messaging and literacy development. British Journal of Psychology 102(3): 431-442. 


\section{Summary}

The aim of this paper was to study the characteristics of SMSes in a population for which there is currently only limited data: young adolescents (girls and boys) between 11 and 12 years of age. The analysis focused on a corpus of 4,524 SMSes sent by 19 informants in everyday real-life situations over a one-year period. At the beginning of the study, the participants were complete novices. This study sets forth a new analysis grid which distinguishes between two categories of textisms which were defined based on the following cognitive processes: a) textisms which are consistent with the traditional written code of grapheme-phoneme correspondence and b) textisms which break with this traditional code. On the whole, the density of textisms was .52 and .26, respectively, for each kind of textism. The results showed an increase in the density of textisms with SMS experience (from month 1 to month 12), but also a variation depending upon the type of textism and the gender of the texter. For boys, the density of both types of textisms increased with SMS experience, while for girls, the density of textisms only increased for textisms which broke with the code. The results were interpreted in terms of the construction of an SMS register with specific linguistic markers resulting from a different use of traditional writing rules or the use of inventions as compared to traditional writing.

\section{Authors' addresses}

Josie Bernicot

Université de Poitiers - CNRS

Centre de Recherches sur l'Apprentissage et la Cognition (CeRCA - MSHS) - Bâtiment A5

5 rue Theodore Lefebvre

F-86000 Poitiers, France

josie.bernicot@univ-poitiers.fr

Phone: +33 (0)5.49.45.46.10

Fax: $+33(0) 5.49 .45 .46 .16$

Antonine Goumi

Université Paris Ouest Nanterre La Défense

Laboratoire de Psychologie des acquisitions et des interactions en contexte PACO - EA 4431

200 avenue de la République

92001 Nanterre Cedex, France

antonine.goumi@u-paris10.fr
Olga Volckaert-Legrier

Université Toulouse 2

Laboratoire PDPS Axe 4 - Psychologie des

acquisitions et des apprentissages

5 allées Antonio Machado

31058 Toulouse Cedex 9, France

olga.volckaert-legrier@univ-tlse2.fr

\author{
Alain Bert-Erboul \\ Université de Poitiers \\ CNRS, Centre de Recherches sur l'Apprentissage \\ et la Cognition (CeRCA - MSHS) - Bâtiment A5 \\ 5 rue Theodore Lefebvre \\ F-86000 Poitiers, France. \\ alainberterboul@gmail.com
}


Josie Bernicot, Olga Volckaert-Legrier, Antonine Goumi, Alain Bert-Erboul

\section{Appendix}

Screenshot of the software enabling the researchers to receive the SMSes sent by the participants

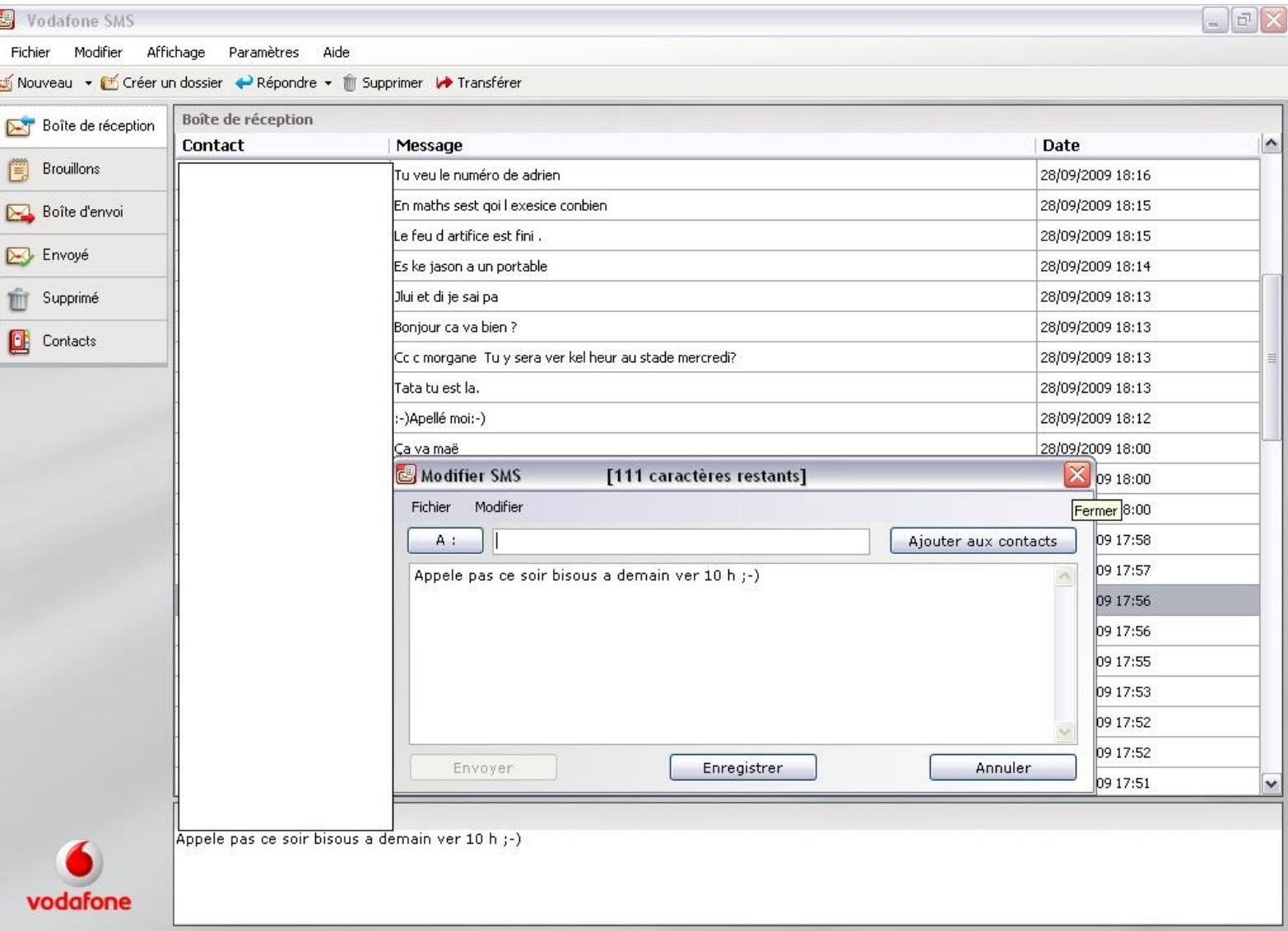

